This item was submitted to Loughborough's Research Repository by the author.

Items in Figshare are protected by copyright, with all rights reserved, unless otherwise indicated.

\title{
Journeying in the eighteenth-century British verse epistle
}

PLEASE CITE THE PUBLISHED VERSION

http://www.informaworld.com/smpp/content $\sim \mathrm{db}=a$ all content=a908686717 frm=titlelink

\section{PUBLISHER}

(C) Routledge (Taylor \& Francis Group)

\section{VERSION}

AM (Accepted Manuscript)

\section{LICENCE}

CC BY-NC-ND 4.0

\section{REPOSITORY RECORD}

Overton, W.J.. 2019. "Journeying in the Eighteenth-century British Verse Epistle". figshare. https://hdl.handle.net/2134/4253. 
This item was submitted to Loughborough's Institutional Repository (https://dspace.lboro.ac.uk/) by the author and is made available under the following Creative Commons Licence conditions.

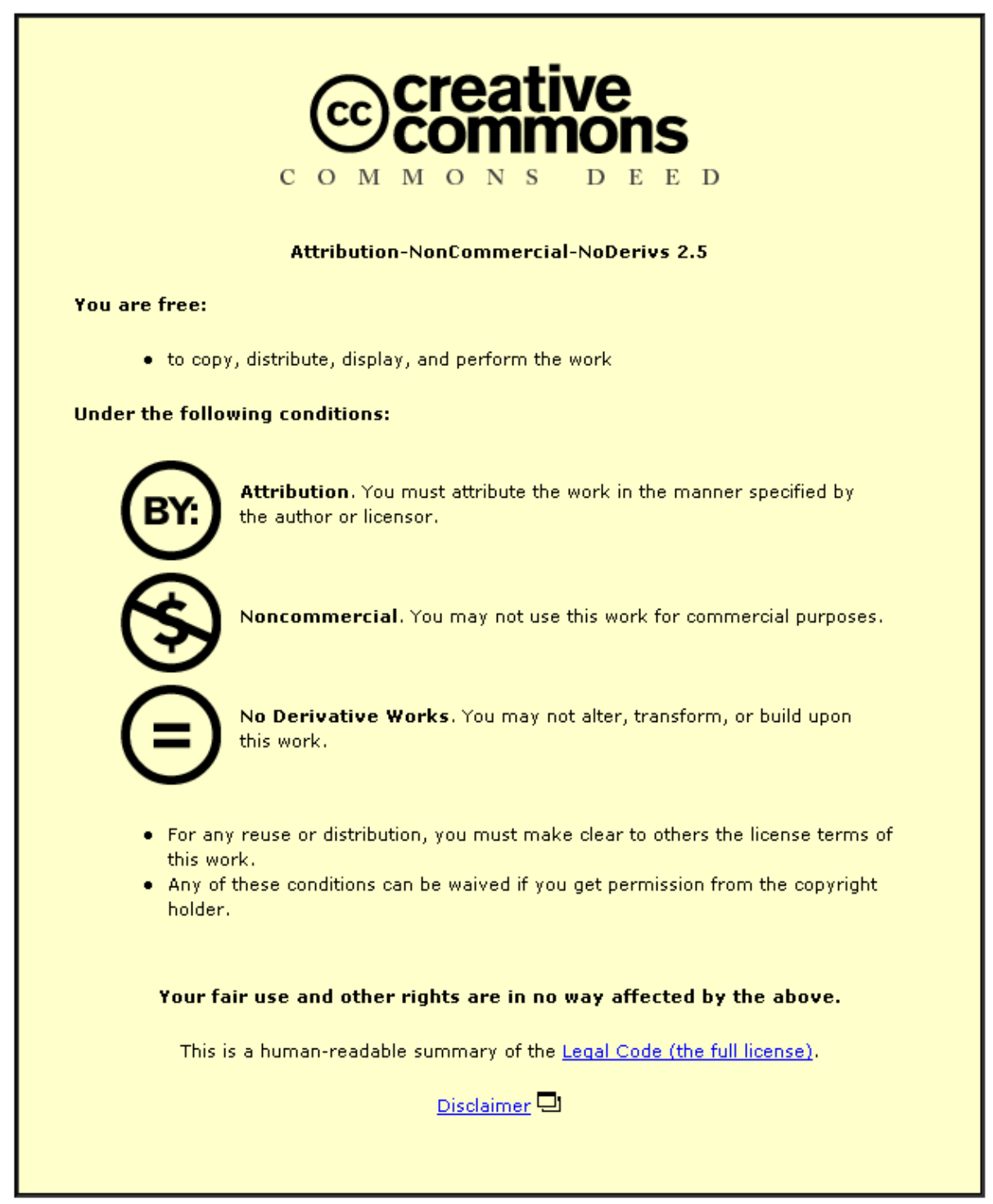

For the full text of this licence, please go to: http://creativecommons.org/licenses/by-nc-nd/2.5/ 


\section{Bill Overton}

'Journeying in the Eighteenth-Century British Verse Epistle'

Early in an essay about the history of transport and communication in England and Wales, Nigel Thrift declares that the movement from one place to another of people, goods and messages 'cannot be split apart'. ${ }^{1}$ Until reliable devices were developed to convey messages electronically, the same means by which people travelled also transmitted information. In this way, the history of the Post Office, founded in 1660, is intertwined with improvements in the road network and shipping services, and, in the nineteenth century, the rapid growth of the railways. After 1660, news circulated in increasing volume and rapidity, both through the growth of newspapers and magazines and through what Karina Williamson calls 'a vast increase in letter-writing of all kinds'. ${ }^{2}$ And, though travel did not become easier in much of Britain until the latter part of the eighteenth century, expanding commerce and industry led to considerable increase in the movement of people as well as goods.

This essay is about a literary form that shows with special interest and vividness how these two developments intersected. Although the verse epistle has a long history, stretching back to Horace and Ovid, and although it is still alive today, its heyday was in the eighteenth century. ${ }^{3}$ This was a period when the letter, in prose or verse, was a staple form not only for literature but also for publications in history, philosophy and science among other topics. William C. Dowling draws attention not only to such obvious examples in fiction as Samuel Richardson’s Pamela (1740-1) and Clarissa (1747-8), and Tobias Smollett’s Humphry Clinker (1771), but also to 'the hundreds of minor epistolary novels produced during the period' and, equally, 'the hundreds of works of philosophy, theology, aesthetics, political theory, controversy, conduct and travel whose titles give no hint that they, too, are written in 
Overton: page 2 of 46

the form of letters or epistles'. Illustrating the point, Dowling cites various epistolary works rarely recognised as such, including Bolingbroke’s The Idea of a Patriot King ([1740]), Goldsmith's History of England (1764), and Burke's Reflections on the Revolution in France (1790). ${ }^{4}$ Discussing letters of all kinds, Clare Brant goes so far as to call them 'the most important kind of writing in the eighteenth century'. For this reason, the period could be dubbed the century of the letter. But what is surprising to a present-day reader is how many letters were in verse. Many thousand verse epistles were written and published in the period, on all kinds of subjects and in a wide range of styles and tones. The large numbers that were written without a view to publication provided a form of entertainment and a way of demonstrating wit and cultivation. Although normally addressed to a single correspondent, it was often expected that they would also be read by friends and relatives.

The increase in letter-writing and reading was a function of greater mobility. According to Nigel Thrift, one consequence of improved transport in eighteenth-century Britain was that 'this was a highly mobile society by the standards of its time (with the exception of certain sections of the population, like farmers and yeomen)' ${ }^{6}$ Indeed, at the end of the period, in 1797, a writer in the Critical Review remarked: 'This may be called the age of peregrination; for we have reason to believe, that the desire of seeing foreign countries never before so diffusively operated. ${ }^{7}$ But indigenous travel also greatly expanded, for 'peregrination’ was part of a further, related development that might be termed an ideology of mobility. In a chapter entitled ‘The Production of Mobilities', Tim Cresswell contrasts classical assumptions about motion with those of early modern science:

Movement to Aristotle was a result of potential already in an object that had to be fulfilled. The natural state of things was rest. To Galileo, the natural state of things was movement with rest being a mere accident. ${ }^{8}$

Cresswell goes on to relate Galileo's thinking about movement to that of William Harvey on 
the circulation of the blood and Thomas Hobbes on liberty. More strikingly still, he then points out that, in his Commentaries on the Laws of England (1765), William Blackstone argued that mobility 'was an absolute right of man', quoting Blackstone’s definition of the right to personal liberty 'as the power of "loco-[motion]" or the ability of "changing situation, or removing one's person to whatsoever place one’s own inclination may direct; without imprisonment or restraint, unless by due course of law",. 9 These ideas went hand in hand with the development of such principles as the freedom of the press and the right to correspond without surveillance or interference. ${ }^{10}$

This developing ideology of mobility lies behind the increasing opportunities in the eighteenth century for many people not only to travel without other impediment than those caused by the weather and the imperfections of the transport systems, but also to correspond freely by letter. As letters are normally motivated by absence, and as poems are often selfreflexive, it is not surprising that some verse epistles focus on the travel that has brought absence about. The kind of poem that results is designed both to communicate from distance and to represent in some way the experience of having been transported - or, if written en route, of being transported - to a different place. Such poems form, then, a sub-genre not only about travel and communication, but also about a particular form of their inter-relatedness. This essay considers a wide range of examples, all of which are listed for convenience at the end.

The essay's aim is not only to identify and illustrate the sub-genre of the travel epistle, but also to bring to light a kind of evidence little considered previously about the experience and representation of travel in the eighteenth century. Only one of the poems discussed, 'Epistle to Burlington', is by a canonical writer (John Gay). The others are very little known, if known at all - indeed, one, Thomas Pearson's 'Epistle to D. B. from T. P.', seems to survive in a single copy. It is surprising that evidence of this kind has been overlooked, for the need on 
Overton: page 4 of 46

the part of the writers to represent their journeys in such ways as to interest their addressees not only produces writing that is often lively but also, in most of the examples, some sense of what different forms of travelling in the period were actually like. This is important because, as Robin Jarvis observes, summarizing an argument put by Anne D. Wallace, 'the travel process is ordinarily suppressed in much contemporary travel writing, and it is remarkably difficult to determine in many cases just how the traveller is getting about' ${ }^{11}$ Like journals and diaries, letters often provide just this kind of information, especially when aimed in part at entertaining their addressees. In other words, the fact that they are letters as well as poems is crucial. Even when written in verse, a letter allows for the same kind of intimacy and immediacy as a diary or journal - whether or not, as I shall indicate, the writer chooses to embrace these.

Furthermore, as Clare Brant points out, unlike journals, 'letters are normally dialogic'. In the eighteenth century, she goes on to infer, 'The open form of a letter was a formal analogue to that open-minded spirit of enquiry supposed to characterise travel; the mobility of correspondents symbolised progress. ${ }^{12}$ Although allowances have to be made for literary artifice, and in a few cases for humorous exaggeration, by and large the accounts I will discuss compare well for accuracy with evidence about travelling from the period. The means of transport vary widely, especially as some writers resort to several different ones on their journeys, and so too do the purposes and the conditions of travelling. At the same time, the forms of expression are also very different, particularly according to the nature of relations between writer and addressee. For these reasons it is important to set the poems in a literary as well as a social-historical context before discussing them in detail.

In this respect, three points about the verse epistle are crucial. The first has already been stated: that it is both poem and letter. A key implication of this double status is that, while a verse epistle may possess any or all of the formal properties of correspondence, including salutation, valediction, date of despatch and writer's address, it will always demonstrate at least 
some of the formal and other properties of a poem. Second, from its beginnings in the works of Horace and Ovid, the verse epistle has normally addressed not only a named person as intended recipient, often called the 'internal' addressee, but also, implicitly and sometimes explicitly, a wider audience, often called 'external' ${ }^{13}$ In most epistles, this double mode of address follows from the fact that they are poems, literary works specifically designed for circulation if not print publication. It has to be remembered, however, that verse-writing was not an uncommon accomplishment or form of entertainment in the eighteenth century, and various verse epistles have survived from the period that appear to have been intended for their addressees alone or at most for a small circle of relatives or friends. Third, in her book Epistolarity, which is chiefly concerned with epistolary fiction, Janet Altman recognises that 'the letter writer's language is shaped by the specificity of his reader'. ${ }^{14}$ This is what Clare Brant means by the word 'dialogic' already quoted; and, although it is possible to overstate the point, the nature of what Altman calls the 'addressee-consciousness ${ }^{\text {,15 }}$ of the letter-writer is always significant. An obvious example is the extent to which a letter-writer may refer to private knowledge shared with the addressee. Less obvious are the different ways in which the writer may seek to appeal to the addressee’s interests, concerns or values. An important effect of 'addressee-consciousness' is to complicate the verse epistle’s double mode of address. While, for example, some forms of intimate reference may be unintelligible to external readers, it is possible to present them so as to enable such readers to enjoy the illusion of occupying the addressee's position. The three principles just outlined will be shown in action in what follows. A very specific sign of the fact that verse epistles are also letters is their form. In the eighteenth century this was particularly important, because different verse forms had different connotations and brought a whole range of generic expectations into play. The poems in the sample are quite varied metrically. Fourteen are in iambic pentameter couplets, the stock form of the period especially for verse on serious subjects. A further six are in the other staple 
Overton: page 6 of 46

eighteenth-century metre for rhyming couplets, iambic tetrameter; but three are in anapestic tetrameter couplets and two are in quatrains - one in elegiac quatrains, as with Gray’s 'Elegy Written in a Country Churchyard', one in the unusual form of anapestic trimeters rhyming alternately. Although a large number of the poems are in iambic pentameter couplets, this does not mean that their versification is the same, for the form is capable of considerable variety and flexibility. At the elaborate end of the spectrum are heroic couplets. These are characteristically closed (in other words, the sense rarely runs on from one couplet to another), so enabling systematic patterns such as those of balance, antithesis and chiasmus; and they are complemented by elevated diction. Examples are the epistles by Sneyd Davies, Stephen Duck, Eyles Irwin and John Whaley, ${ }^{16}$ all of which appeal to elite cultural values. The informal examples much more often use open couplets, in which lines may run on beyond each rhymed unit, sometimes with the humorous effects produced by hypermetrical end-of-line light stresses and deliberately forced rhymes. For example, John Byrom’s epistle about a highway robbery, which is in ten-line stanzas of iambic pentameter couplets, ends a stanza by rhyming 'defending' with 'Fire-Engine' - a forcing together of discordant sounds that, quite apart from its ludicrous term for a gun, is, its editor remarks, 'Probably the worst rhyme to be found in our author'. ${ }^{17}$ Such effects, however, are more common in tetrameter couplets, the four feet of which, compared with the five in pentameter, easily lend themselves to humour and informality. All six of the poems in the sample in tetrameter couplets exploit them. Tetrameters by no means always carried humorous connotations in the eighteenth century, but anapestic metre did so more often. The extra light stress in each anapestic foot suits it to broad comic effects, as in Moses Mendez’s account of his journey to Ireland or Eliza Day’s, in bouncy trimeter quatrains, of an uncomfortable expedition in the Alps. ${ }^{18}$ Again, extra light stresses combined with comic rhymes may amplify the humour, as they do in all three of the poems in this metre. 
Overton: page 7 of 46

Especially in the eighteenth century, verse form often indicated genre, and the poems are also generically diverse. No fewer than 19 are essentially familiar verse letters, while four belong to a subgenre that was popular in the eighteenth century but is little regarded today: the complimentary epistle, usually written to a respected friend or colleague or to an actual or potential patron. The most unusual examples generically are Georgiana Cavendish's Passage of the Mountain of Saint Gothard, which is an epistolary ode addressed to her children; and the poem from 'Cynthio' at the Cape of Good Hope, which is a kind of heroic epistle, though written from a man travelling away from a woman rather than, in the original Ovidian form, from a woman to the man who has abandoned her. ${ }^{19}$ It is Cavendish who adopts the decorous form of heroic quatrains, whereas ‘Cynthio’ follows almost all writers of heroic epistles in English by using heroic couplets. In this way, the two poems illustrate how genre could relate to verse form. Similarly, epistles addressed to patrons are much more likely to be in iambic pentameter couplets, more or less formal according to the nature of relations between writer and addressee, whereas those in tetrameter couplets are more likely to be familiar epistles addressed to friends or relatives. However, just as the same verse form can be used in various ways, even the familiar epistles show generic diversity. Though all have a strong narrative element, some, like Thomas Pearson's, are in effect actual letters; ${ }^{20}$ and, while several treat the stock eighteenth-century topic of town versus country, John Thelwall’s 'Epistle to Mercutio’ is a kind of impromptu prothalamion, Priscilla Pickering’s ‘Journal from Litchfield to Chester’ partly consists of dialogue between her and her fellow-passengers, ${ }^{21}$ and most of John Whaley’s ‘Journey to Houghton’ is a sort of gallery catalogue, describing the art treasures collected by Sir Robert Walpole.

Travel on foot The sample is fairly representative in that, between them, its 25 poems depict all the main 
Overton: page 8 of 46

forms of travel available at the period. I will discuss them in order from the most simple forms to the most complex - in particular, those that present several different means of travelling in the same epistle. In two of the poems, travel is exclusively on foot. Probably imitating two poems to be considered later, John Gay’s ‘Epistle to Burlington’ and Stephen Duck’s 'Description of a Journey to Marlborough', William Vernon describes a journey he made from near Wolverhampton into Wales. ${ }^{22}$ At this time, pedestrian travel had probably not acquired the democratic connotations it would have in the 1790s and which I will consider later. Instead, it is likely that, on the income of a private soldier, Vernon would have had little choice to travel otherwise. He was one of the labouring-class writers who found their way into print after the success of Duck and others in the 1730s, and his poem, like Duck's, is in conventional heroic couplets. Just as Gay and Duck had addressed their poems to patrons, so he gave his a complimentary frame by addressing it to a figure who had favoured him, the Reverend $\mathrm{Mr}$ Williams of Weston. ${ }^{23}$ He made his journey for pleasure, although, surprisingly, it was winter. A traveller on foot is likely to be only too well aware of the weather, and Vernon describes a heavy rainstorm but also a fine following morning, 'as mild as May' (7). His route took him to Shifnal on the first day, to Wellington on the second, and then to Shrewsbury. As the poem goes on, he shifts increasingly from travelogue to description and reflection, especially over historic sites - so much so that he does not refer to his return journey at all. One of the most interesting features of his account is that at Shrewsbury he takes a guide, for, he asks, 'who would rove alone, / Where manners, customs, language are unknown' (9). The two get as far as Mathraval, a few miles west of Welshpool, legendarily the seat of the ancient kingdom of Powys, at which point his poem becomes a meditation on transience, wild rural beauty and 'old honesty' (12). Whether or not such themes appealed to Vernon - and there is no saying that they did not - they were probably calculated to please not only his patron but also the genteel reader. 
Overton: page 9 of 46

The other epistle describing a journey on foot is also by a labouring-class writer and it is also in iambic pentameter couplets. But in two further respects it could hardly differ more. First, Alexander Wilson’s ‘Poetical Letter to William Duncan’ describes a trek in North America, but not one he had made himself. ${ }^{24}$ Written while he was working as a schoolteacher in Milestown, near Philadelphia, years before his epic journeys on foot as an ornithologist, it is addressed to his nephew, with whom he had escaped from poverty in Scotland a few years before. The journeys it describes - for it also evokes Duncan's return - are, then, wholly imaginary. Second, the purpose of the journey is not pleasure but employment, for Duncan was travelling to settle and farm land in New York State. Wilson is inspired not only by friendship and kinship but by a wish to share the same experience, at least in spirit. He declares, for example: 'I saw you then, hope sparkling in your eye, / Pierce the deep wood, and scale the mountain high’ (ll. 13-14). The two must have researched Duncan's route, as Wilson can cite the main landmarks and anticipate that walking it will take ten days. He spends over half of the poem on a description of the journey that, considering he had not travelled it himself, is surprisingly detailed. Places he names on the way are 'Wilkesbarre's fertile plains' and 'Wilhalvossing' (ll. 23, 37), but more important are such landmarks as a river called Lelu, 'the Allegany blue' in the distance, the site of a massacre of settlers by Native Americans, the river (clearly the Susquehanna) that much of Duncan's route follows, a large hill near Tioga, and finally, after 'Ten days of tedious toil and marching past', Lake Seneca (ll. 15, 24, 28-30, 31, $57-60){ }^{25}$

In the middle part of the poem Wilson imagines Duncan's work in clearing land to farm it, and encourages him in the virtues of labour and independence, building up to an exultant celebration of the opportunities that life in America offers. Beginning by looking back to their journey to the New World, 'when of late we ploughed the Atlantic waves, / And left a land of despots and their slaves' (ll. 63-4), he goes on to praise the freedom from 'proud lordling', 
Overton: page 10 of 46

'scoundrel landlord' and ecclesiastical 'thief in black' (ll. 85, 86, 87) that enables hard-working people to enjoy ‘Plenty’s smiling bliss’ (l. 92) without oppression. In his final verse paragraph he asks his friend to come back once he has established himself successfully. But this is no simple invitation, for he imagines Duncan returning in winter, and, through a confident paradox, all the more easily for the snow and ice that might be expected to present all but insuperable difficulties. In a passage full of passionate vitality, he appeals to his friend to

Ascend the fleeting height, and, like the wind,

Sweep o'er the snows and leave the woods behind;

Along the rugged swamp and mountain high,

'Mid rocks and narrows, make thy horses fly. (ll. 101-4)

Couplets such as these, though formally regular, draw power and energy from the positioning of verbs at the beginnings or endings of lines, the former often reversing the normal iambic stress - 'Sweep’ here, and earlier, for example, 'Pierce', 'Pass', and 'Cross' in successive lines (ll. 14-16). The whole poem has a similar inspiring momentum, and this is part of its function as a verse epistle. Written fairly soon after Wilson's arrival in North America, it expresses a stereotypical settler's view of Native Americans and an optimistic outlook of the difficulties of travelling on foot, especially in winter. Yet, while Wilson's expressed wish in evoking Duncan's return journey is to welcome him back and celebrate their friendship 'with choicest store / Of wine and roast-beef' (ll. 115-16), the effect, and probably the implicit aim, is to encourage him in the laborious tasks ahead. Full of buoyant hope and optimism, though recognising they are 'haply never more to meet' (l. 4), the epistle is a striking imaginative account not only of travel on foot in the New World but of Wilson's ability to evoke both the journey and what was at stake in it. 
Travel on horseback

Of the four poems in the sample about travel exclusively on horseback, three are familiar epistles and one is complimentary. The best known not only of these four but of all 25 examples is Gay’s ‘Epistle to Burlington', subtitled ‘A Journey to Exeter’. First published in $1717,{ }^{26}$ the poem describes one of the journeys its author made for health and recreation to his native Devon. Leaving London on a Sunday, when there is less cart traffic because, Gay says, 'still on Sundays Country Horses rest' (l. 10), the journey takes five days in stages of between about 30 and 40 miles, and it includes a short trip by ferry because the bridge at Staines is flood-damaged (ll. 19-20). As David Nokes points out, the epistle 'takes the form of a verse Baedeker', ${ }^{27}$ offering many lively and colourful local details, including a reference to dangers from highwaymen at Bagshot Heath (ll. 21-2), ${ }^{28}$ the farming out of illegitimate children at Popham-Lane (ll. 34-46), and the attractions of the three girls' boarding schools at Salisbury. Gay and his two unnamed companions stop overnight at 'Hartley-Row' (1. 23; now part of Hartley Wintney in Hampshire), Stockbridge, Blandford Forum and Axminster. The poet was a poor rider, and, though he makes little of this, he shows a keen awareness of the experience of travel on horseback. After oversleeping on the first night, he rues the 'Twelve tedious Miles' during which he and his fellow-travellers have to endure 'the sultry Sun’ (1. 33), and, next day, the same distance over 'th' unbounded Plain' of Salisbury, where there is no shelter (1l. 57-60); also unwelcome is the rainstorm on the last day that 'Stream'd down [their] Hats, and smoak'd along the Road' until they come upon an inn (ll. 119-21). Gay is understandably sensitive to different travelling surfaces, observing that the riding is easy 'O'er the green Turf' before Blandford (1. 77), but that the 'true Roman way' after Dorchester (l. 91) gives way to 'Bridport's stony Lanes' (1. 95), and that the hills of Dorset delay arrival in Axminster till night (ll. 101-2). But he gives a sense of perspective too, as when, approaching Salisbury, he 
Overton: page 12 of 46

exclaims: 'See Sarum’s Steeple o’er yon Hill ascend’ (l. 68), and points out the ‘scatter’d Farms and Groves’ visible ‘from the steep’ above Honiton (ll. 115-16).

Gay addresses his epistle to Burlington not only as his principal patron at the time but as the provider of his horse: 'You knew fat Bards might tire, / And, mounted, sent me forth your trusty Squire' (ll. 5-6). However, though he begins the poem with a compliment to the wealthy champion of Palladian architecture who can 'bid stately Piles ascend' (l. 1), he not only avoids flattery but hardly refers directly to his addressee at all in the poem that follows. Instead, his tribute takes the form of the kind of entertaining circumstantiality cited above, increasingly enlivened by humour, as when he mentions sketching his companions while they sleep (ll. 858), going to bed in a woman's smock while his clothes are washed and dried overnight (ll. 1038), and, with a mock-heroic simile, being shaved by a woman the next morning 'Soft as when Venus stroak'd the Beard of Jove' (l. 114). The absence from the poem of details comprehensible only to an insider suited it well for publication, as with Horace's Satire 1. 5, in which he describes a journey from Rome to Brundisium - although, as Gay’s editors point out, 'he offers not a single parallel to it in details' ${ }^{29}$ In this respect it contrasts sharply with a prose letter about a long journey to the West on horseback that Gay wrote during the same period to Martha and Teresa Blount. ${ }^{30}$ Although it has been assumed that verse epistle and letter describe the same journey, ${ }^{31}$ this is unlikely. Not only do the two accounts have almost nothing in common, but the letter makes it clear that Gay has only one companion, Pope; that, as Maynard Mack observes, they stop at Mapledurham, near Reading, 'to pick up a steed for Gay'; and that the destinations are different - Bath rather than Exeter. Furthermore, while the journey described in the epistle took place in June 1716, with first publication in the following year, that described in the letter is assigned with fair probability by Mack to August 1717. But the two most striking contrasts between letter and poem are that the letter is from the horse's mouth, Gay having written it in the guise of his steed, and that it is oriented to its addressees 
Overton: page 13 of 46

and, at most, their immediate circle rather than to a wider readership. Gay has the horse assume, for instance, that his rider is a good Catholic because he keeps 'mentioning the Word Pope’; convey gallant flattery when he says he overheard his master telling his friend he would have thought the ladies in a town through which they pass 'the prettiest he ever saw, had he never been at Maple-durham'; naively assume that Gay gives a country girl half a guinea to compensate her for the loss of her straw hat that the horse has eaten, rather than for sex; and end with a further compliment - that two other horses report that, in a wood close by, 'they saw upon ev'ry Maple-tree there the words Teresa and Patty'. The letter's amusing whimsy is aimed to appeal to its private addressees, and to them alone, rather than the wider readership Gay certainly intended for his epistle.

Although Gay begins with a courteous reference to Burlington, his epistle is familiar rather than complimentary. In this respect it is quite different from the poem in which, writing to an unnamed addressee, John Whaley describes his journey from Norwich to Houghton Hall in Norfolk, and, in particular, the Hall itself and the works of art collected there by Sir Robert Walpole. ${ }^{32}$ Though Whaley also uses iambic pentameter couplets, they are more formal than Gay's, as in the occasional triplets from which Gay wholly abstains; his diction is more artificial; and he includes explanatory footnotes, especially on specific paintings. Correspondingly, Whaley provides few details about the experience of travelling - and one of those he does give, on finding none of the food and provender expected at an inn on the way, is an allusion to Gay's poem. ${ }^{33}$ Instead, he uses the lines in which he describes his journey - 90 out of a total of 359 - partly to comment on sites of interest and partly to compliment those associated with them, such as Glocester Ridley, vicar of Weston Longville (30-1), and the second and third Viscounts Townshend (33-4). As a former tutor of Horace Walpole, however, he is mainly concerned to compliment the Walpole family. This he does indirectly through his description of the works of art at Houghton, which had been described in 1739 as 'the most 
Overton: page 14 of 46

considerable now of any in England', ${ }^{34}$ directly through his eulogy on Catherine Shorter, Sir Robert Walpole’s first wife (50-1), and, more briefly, Walpole himself, who had died only a few months before the poem was printed $(44,51) .^{35}$

As verse epistles, the kinds of information and entertainment that Gay’s poem and Whaley's seek to provide are tailored to their internal and external addressees. The other two poems describing travel on horseback had lesser ambitions, as their informal iambic tetrameter couplets indicate, and neither of the journeys they relate was for pleasure. Stephen Chatterton's ‘The Journey. An Epistle to Mr. Pardoe’ describes in some detail travelling from Walsall to Aspatria in Cumbria. ${ }^{36}$ As Chatterton begins by declaring himself 'banish'd' from his 'native soil', leaving his 'friends and wife' behind (72), he probably had to travel for business or professional reasons, presumably involving a considerable time away, and there are tears on both sides at his parting. He estimates the length of his journey at 180 miles, and, leaving at six in the morning on a day in late June, it takes him five days, stopping at Wigan, Preston, Lancaster, Kendal and Carlisle. The details of his journey with which he regales his friend are fairly miscellaneous. They include a blind fiddler playing ‘quite free from melancholy’ and in apparent ignorance of his danger from the cart full of lime on which he is travelling (73); patriotic reflections on the Battle of Preston, fought during the Jacobite Rising of 1715; a poor but expensive dinner at Lancaster made up for by one of 'trout, green geese, green pease, and ale’ at Kendal (74); the contrast between the poverty of northern Lancashire and the fertile, populous south; and the desolation of the road to Shap, high enough in parts for him to see clouds beneath him, where the landscape is dreary and the ground barren (75). Chatterton enlivens his poem, and probably sought to amuse his friend, with occasional comic rhymes, as when, having mentioned crossing 'the winding Mersey', he adds: 'Which you have done, ere now, I dare say' (73). Also, in a manner suitable to epistolary writing, he coordinates his addressee's act of reading with his own of travelling when he instructs: 'Read farther, and next 
day you'll find / Your friend at Kendall, where he din'd'. His destination, however, cannot have held much to attract him, for he ends the poem abruptly with a brief valediction after mentioning that he is now staying there after arriving 'thro' show'rs of rain': 'Wishing the health of all my friends, / And here my rhyming story ends’ (75).

Like Chatterton, Thomas Gilbert also describes himself as 'Banish'd' - though in his case by what he calls 'Fortune' (212), presumably lack of funds. His 'Familiar Epistle to Doctor Reeve, in London' combines reflections not only on his journey to York but also on the stock eighteenth-century topics of country versus city, the attractions of rural retirement and the search for happiness in a transient world. ${ }^{37}$ Gilbert offers little detail on his journey, except claiming wryly that he composed the epistle while 'riding on a jaded horse, / On whom the spur had lost its force' (215). Instead he comforts himself on having to leave London and its 'gallant scenes at park and play' (211) for 'calm content' in 'an humble, rural cell', while his friend has to 'Attend the busy hum of men, / And live by learned dash of pen' (213). His poem is characteristic of the male-authored 'Familiar Epistle' in its informality and insouciance. He jokes at the improvised nature of his verse - 'While you, by inclination hurl'd, / (Excuse the phrase, that rhimes to world)' (213) - and also at his friend's profession as a doctor, slotting into a wish about absence of poverty and disease the parenthesis 'But then indeed you'd lose your fees' (214). Thoughts such as these give the impression of having been literally, as he claims, made up on the hoof, like the ending: 'For now (thank God) I'm come to York' (216). Yet Gilbert not only invokes two other epistolary conventions with an eight-line 'PS.' and subscription of place and date ('York, March 16, 1740-1'), but gaily undermines his previous celebration of rural contentment by referring to the pleasures he is about to enjoy at Skelton Castle, home of his friend John Hall-Stevenson and the club of 'Demoniacs'. ${ }^{38}$ In this sense his journey may have been for pleasure after all, though only an intimate would probably have been able to gauge how far his regret at leaving London was tongue in cheek. 
Travel by carriage

The three epistles describing journeys by stagecoach are all familiar, and their loose, even ungainly, iambic pentameter couplets reflect freedom from literary pretension. At $2 \mathrm{~d}$ or $3 \mathrm{~d}$ a mile, plus tips, and, on journeys taking more than a day, bed and board en route, this form of travel was cheaper, but it was subject to greater discomfort and inconvenience. ${ }^{39}$ The three poems show this vividly and in different ways. Although William Cockin spends most of his long epistle to George Romney, the painter, considering life in Westmoreland after a prolonged stay in London, he summarises the experience of coach travel in ten packed lines:

From first to last 'twas here and there a town,

A slough, a foot-pad, or a bridge thrown down,

A scream, a bounce, a pray’r, a queerish song,

Ho! Coachman, stop, or damn you drive along,

To bed, to board, to stool, now out, now in,

Jog, jog, a-jog (ye Gods!) through thick and thin.

At length howe'er (though something sinew-grown,

And eke benumb’d, yet free from broken bone)

Quite safe and sound (for which I thank thee, Fortune)

Your Friend salutes his homely house at B-N. ${ }^{40}$

Cockin describes the coach as a 'new-fashion'd kind of jail', and ironically commends its departure from London at a time when travellers cannot see the 'num'rous joys' they are leaving (79-80). Departing at midnight from a long-established coaching inn, the Swan with Two Necks in Lad Lane, ${ }^{41}$ the coach reaches Finchley shortly before seven (78-80, 84). Once 
the travellers can look around them, Cockin notes no pleasures from the scenery. He points out, for his artist friend, 'The greasy semblance of a dull POUSSIN' on one side, and, on the other, 'a troop of Gipsies' composing 'The filthiest CALLOT that was e'er display'd'; but the 'Sculpture' is even worse: 'five poor Bronzes dangling in their chains' on a gibbet (85). ${ }^{42}$

A footnote to Cockin's poem (92) indicates that he made his journey in 1769, by which time, though he mentions a foot-pad, the danger of highway robbery had greatly decreased. Writing over 50 years earlier, shortly before Gay was to celebrate Macheath in The Beggar's Opera, John Byrom spends most of his epistle describing humorously how he and his fellowpassengers were robbed by a highwayman in Epping Forest on the two-day journey from London to Cambridge. ${ }^{43}$ Byrom gives few details of his journey, except that the coach left from the Bull in Bishopsgate Street; that he was sorry to leave his friends in the Shorthand Society, of which he was Grand-Master, and that the coach was full - the other passengers being two Cambridge fellow-commoners, a bricklayer from King’s Lynn and his wife and cousin. Instead, he contrasts the students' bravado before the highwayman arrives with their complicity once he threatens them, and then with his own response: 'My Heart (for Truth I always must confess) / Did sink - an Inch exactly - more or less’ (I, 67). Baulking at the guineas given by the students, he gives shillings instead, and the bricklayer follows suit. The outcome, after curses and further threats from the highwayman, is that the latter takes fright and bolts when some shorthand characters cut out in paper, which he takes for magic spells, fall from Byrom's pocket. ${ }^{44}$ Though Byrom presents the whole episode as a farce, his epistle not only indicates that highway robbery was by no means a myth, but also suggests some of the highwayman's nervousness and desperation. His main conclusion is to travel on horseback if he can because it is safer. Indeed, in a letter to his wife in which he relates the same incident, he says he has sent for his boots so that he can ride back to London instead of taking the coach. ${ }^{45}$

The latest of the poems describing stagecoach travel reflects the improvements in safety, 
Overton: page 18 of 46

speed and comfort that became widespread towards the end of the century. Written probably around 1790 by Priscilla Pickering, née Pointon, it describes a journey of 75 or so miles from Lichfield to Chester. ${ }^{46}$ Pickering does not mention the departure time, but, as the coach leaves at night in midsummer and arrives in Chester at six in the evening, the journey must have taken between about 15 and 18 hours. As Pickering had lost her sight when a child, it is not surprising that she limits her account chiefly to the passengers 'close confin'd' with her in the carriage (35). These consist of four young men who, to her disgust, snore through the part of the journey that takes place at night, and an elderly unmarried woman who inveighs against 'the Fashions of the age' (36). After relating this harangue, Pickering gives her response, which spurns prudishness as well as modishness and which is probably also aimed at the unmarried niece to whom she is writing. Her dealings with the young men are less successful, for, when the coach stops at Nantwich for dinner, they get her to pay more than her share by leading her to believe that they are treating her for wine. She ends the poem by denouncing them but praising their native city, possibly in part as a bid to attract local subscribers. ${ }^{47}$

The epistolary character of all three of these poems is clear. Those by Byrom and Cockin are topped and tailed with salutations and valedictions, for both of which Byrom manages rhymes (Cockin only rhymes the latter, though he sets it out with humorous mock-formality), and they are studded with allusions appropriate to their addressees: in Byrom's, concerning the Shorthand Society; in Cockin's, Romney's occupation as a painter and the Lancashire roots he shared with him. However, though Byrom published his poem as a pamphlet, Cockin probably intended his primarily to amuse his friend and mutual acquaintances. ${ }^{48}$ Pickering's poem has fewer epistolary formalities, though it begins with the date - ' 'Twas June the Twenty-fifth, at night' (35) - and ends with a valediction: ‘Adieu, dear Girl' (45). Nevertheless, it conforms to the conventions of the literary epistle of the period in its double mode of address, both private, as in 'Girl' (36), 'my dear' (38, 39), and 'your aunt' (42), and also implicitly public, in its 
Overton: page 19 of 46

reflections on fashion, marriage and spinsterhood, as well as on the city of Chester and its charities.

Journeys by private carriage were more expensive, and the three epistles describing this form of travel correspondingly differ more. While Georgiana Cavendish would have hired carriages and bearers for her crossing of the Alps, and Richard Polwhele may have hired but more likely borrowed a chaise to travel with his wife and children from Exeter to his new vicarage at Manaccan in Cornwall, Francis Fawkes, though not the wealthiest of clergymen, had his own post-chaise to take him from his living at Orpington in Kent to his native Doncaster. ${ }^{49}$ Cavendish's The Passage of the Mountain of Saint Gothard is furthest from the experience of travel. Printed in a sumptuous quarto addressed to her children, its seven pages of historical and other notes all but outweigh its own 120 lines in the elevated form already mentioned of elegiac quatrains. As Amanda Foreman suggests, its motives were probably in part to quash a pirate edition and in part to offer 'a veiled apology to her children for leaving them' ${ }^{50}$ Cavendish's notes give details about her journey that the poem itself excludes, such as the dismantling of her carriages for the mountain crossing. In giving so little detail of what the journey was like, it contrasts sharply with the poems by the two clergymen. Although Polwhele spends only the first 54 of his 164 lines describing the three-day journey, devoting the remainder to an account of his new home and its surroundings, it is clearly not comfortable. He refers to the 'jostling' of the carriage, to being 'cramm'd' in, and to the 'stiffness and heat in the flesh' this produces - including an attack of gout $(247,249)$. Strikingly, he says little of his wife and children, except, humorously, that he was so glum at leaving that they had travelled at least ‘A sabbath-day’s journey', or nearly three-quarters of a mile, before he 'grumbled' a word to them, that an occasional 'squawl' distracts him from composing an ode as they travel (248), and that his wife binds his 'goutified toe' with flannel (249). This is probably because the epistle was man-to-man, its addressee being the physician Hugh Downman. Polwhele, now 
Overton: page 20 of 46

best known for his anti-feminist satire The Unsex'd Females, ${ }^{51}$ seeks to appeal to his friend with a rueful account of his discomfort but also with such details as having just missed on the way a mutual friend who is a justice of the peace and a proficient in the classics. He explains why he gives little further information by exclaiming: 'But why, as no striking adventure befel, / Of my route should I every particular tell?’ (249). The humorous nature of his epistle is clear from its anapestic metre and such comic forced rhymes as 'adust is’ with 'justice' (248) and 'comrade’ with 'bum, ray’d' (248).

Frances Fawkes, writing for the amusement of his wife Anne, is much more circumstantial. Subscribed 'Sep. 6, 1759', his epistle tells how he left Kent on the second of the month and, meeting a Yorkshire-bound friend in London, decided to travel with him to Doncaster in his own post-chaise (105). He provides three main kinds of information about the journey. First, he describes points of interest on the way, ranging from the city's smoke as they climb Highgate Hill, and the gibbets on Finchley Common that Cockin would see ten years later, to the site of the Earl of Warwick's death in the Wars of the Roses at Barnet and the church steeple at Grantham, nearly as tall as that of Salisbury Cathedral $(106,110)$. Second, he describes the state of the roads. H. J. Dyos and D. H. Aldcroft remark that 'comparisons of road conditions prevailing in almost any part of the country at, say, twenty-year intervals after 1750 would undoubtedly show tangible improvements, expressed in terms of less intermittent use, shorter travelling times, more substantial traffic, and more generally felt effects of widespread communications, ${ }^{52}$ On that historical scale, 1759 was quite early, and Fawkes found travelling surfaces, to say the least, variable. At one extreme, towards Stilton, are 'Roads as the well-roll'd terrace plain' (109); at the other, 'a tedious, sandy way' after Newark (110), followed by 'wretched roads' with 'turnpikes devilish dear' before entering 'honest Yorkshire' (111). Worse still, as a result of a detour to visit a friend in Bedfordshire, are 'corn-fields [. . . ] Where chariots never went before' in which his carriage gets stuck (108-9), and that enable 
Overton: page 21 of 46

him to claim: 'And came to Beggary at last' (108, referring to a hamlet now known as Begwary). Fawkes praises the ‘finest turn-pike road' after leaving Stevenage, over which 'The wheels, the numbers, gently roll' (107); and he would have been especially aware of road surfaces if, as his title claims, he really did write the poem 'with a Pencil in a Chaise'. But the subject on which he lavishes most attention is the victualling he and his friend enjoyed on the way. Though the details are too many to itemise, the solids included beef, chicken, roast ham, 'mutton, charming food!' (109), 'Smelts and a rabbet' (110), and even 'Delicious eels - the eels of Trent' (111); while the liquids extended from, heroically, a quart of 'good old Port' (106), 'Warm negus' (107), and coffee, to much unspecified but presumably always 'generous' wine (109). The poem's jaunty iambic tetrameter couplets, with occasional comic rhymes, bring out its humour well; and it not only begins with a formal salutation, 'Dear Anne', but ends with a well-turned valediction saying it is 'Wrote, dearest Anne, at your commands, / And now it flies to kiss your hands'.

Travel by water

Sea-travel was, of course, more hazardous and uncomfortable, and the more so the longer the voyage. Of the six poems in the sample describing travel by water alone, two are about pleasure-trips: Sneyd Davies relates his boat trip from Whitminster into the Severn estuary and up the Wye to Tintern Abbey, while Moses Browne sails from London to Scarborough. Writing to cultured friends including perhaps Charles Pratt, later Earl Camden, Davies presents in genteel heroic couplets such picturesque views as 'The pleasing Villas, Neighbours to the Flood, / The taper Spire, and the surrounding wood', or 'Of Trees and Stone an intermingled Scene, / The shady Precipice and Rocky Green'. ${ }^{53}$ Although he describes the Severn Bore, which he has to go past before his boat can venture downstream, he gives little impression of travelling except from the changing landscape and its new perspectives as, for example, 'The 
Overton: page 22 of 46

Prospects widen, and the Shores retreat' (188), or 'The crooked Bank still winds to something new' (190). Indeed, it is only his remark that 'Oars [. . . ] diversify the View' that indicates that his boat did not rely on sails alone to navigate up the Wye. Similarly, despite his addresses to 'my C _ _ (188), and, near the end, 'my Friends' (191), his poem carries few signs of its epistolary character. Though it describes a journey, it is essentially a poem of retirement, paralleling as it does the passage from Severn to Wye with a move 'from a publick to a private Life’ (189), and ending in 'pleasurable Sadness’ at Tintern (191).

Moses Browne’s voyage to the resort of Scarborough could hardly be more different. First, it was clearly written in friendly rivalry with his friend John Duick, who, a footnote indicates, had published 'Scarborough, A Poem, in Imitation of Mr Gay’s Journey to Exeter' a few years before. ${ }^{54}$ Duick's poem, packed as it is with place-names and allusions, is decidedly dull, while going by sea gives Browne’s the advantage of novelty. Second, Browne made his voyage on a working vessel, quite unlike the pleasure-craft in which Davies was to sail. He may have hit on his plan after reading A Journey from London to Scarborough, an epistolary account in prose printed in 1734, which tells how to bargain for a passage at 'Billingsgate any Day in the Week'. Although the anonymous writer chooses to go by land, he points out that the cost of the voyage is 'about a Guinea, if you diet with the Master, and Half a Guinea or Fifteen Shillings for a Servant'. ${ }^{55}$ Browne follows the convention of pointing out places of historic or literary interest on the way, but with a humorous twist, as when he mentions 'A soft exchange of Compliments’ between ‘Wapping’s courtly Swain’ and ‘the chaste, coy-air’d Nymph of Drury Lane', or 'Cuckold's antient Point', a landmark on a sharp bend in Rotherhithe (206). Similarly, he does not shrink from reporting the less pleasant side of sea-going, remarking that on reaching open sea: 'Here first my Bowels felt unusual Pain', but then his success in fending it off with the 'lenient Pow'r' of brandy (207-8). Browne notes other homely details such as fishing while the ship stops at Harwich for 'Traffick' (208), drinking punch with the mate, and 
Overton: page 23 of 46 having his shirt washed and ironed by the sailors (209). He goes on to celebrate Yarmouth's herrings and to point out the lighthouse at Spurn Head before Scarborough comes into view, which the ship reaches just before a storm. His poem, introducing three further epistles on the pleasures of Scarborough, ends with him enjoying the company of his friends and smoking 'th' ambrosial Pipe’ (211).

Those who travelled to make their fortunes were often less cheerful. The anonymous writer of 'A Voyage to Guernsey, in an Epistle to a Lady in London' laments having to leave his beloved Delia behind, evidently in a desperate attempt to obtain the money that would enable them to marry. ${ }^{56}$ His passage is first stopped short by a contrary wind, causing rough seas even in the bay where the ship has to shelter, and then by rocks at Alderney, on which it runs aground. After putting in to harbour while the hull is checked for damage, and visiting the squalid town, he arrives in Guernsey 'at the close of day, / The fourth inclusive since we put to sea'. Readers of the period would probably have recognised the motive for his journey, as privateers were known to operate from Guernsey. ${ }^{57}$ It is confirmed by another poem from the same writer, dated three months later and entitled 'An Epistle Written on Board the Adv-t-re, Privateer, at Sea to a Lady in Dorsetshire', in which he describes the miserable conditions on board and the brutish crew, perhaps recognising already the folly of his enterprise. ${ }^{58}$ Equally unhappy, though involved in legitimate business, is 'Cynthio', the writer of the epistle from the Cape of Good Hope mentioned earlier, for he has had to leave behind both wife and children ‘the pledges of our faith' (1. 263). Sailing from the Netherlands in 'India's annual fleet' (1. 55), he clearly aims to gain enough wealth to give them a new life together. He describes the voyage, including stops in the Canary Islands and at Cape Town, from where he has to send his epistle before sailing on. Though he expresses his grief at separation, and his unhappiness in an 'Eden' that for him lacks only its 'Eve' (ll. 183-4), he also sketches and comments on what he sees around him in a way that may have been meant to appeal to a wider audience as well as to 
his addressee, including rueful remarks on the Africans who, he claims, 'No wants endure but such as nature gave' (l. 205), and who 'pity us in search of wealth who roam’ (l. 212).

Much more sanguine, as befitting his profession, was the Reverend Samuel Dent, whose 'Epistle to a Friend in England' is about sailing from England to make a new life in Barbados. ${ }^{59}$ His poem, according to the subtitle 'Written at Sea, in December, 1772', looks forward to another earthly paradise, 'Where one perpetual Summer ever smiles’ (4), that will redeem the trials and tribulations of the voyage. Although Dent gives details of, for example, the rigging being prepared for sailing (7), and although he mentions seeing 'huge Leviathan' and 'the gay Dolphin' (9), much of his poem expresses what might be termed imperial uplift. Its tone is relentlessly optimistic, as when he praises an England 'Where George, and Freedom hold their peaceful reign, / And equal good diffuse, and right maintain’ (8), and, especially, when he ends with a tribute to 'fair Commerce' who 'cares alike for Subject, and for King' (10). Needless to add, the slave trade and slave labour that produced the prosperity he celebrates go unmentioned.

All five of the poems discussed so far about journeys under sail are in one form or another of pentameter couplets - fairly informal in Browne's case, elaborate in Dent's, which boasts occasional triplets. While heroic couplets probably seemed the appropriate choice to 'Cynthio' for a poem that recalls the heroic epistle, it is surprising to find them employed for the two epistles about piracy, the form contrasting, almost in mock-heroic fashion, with the hardships, filth and depravity described. For the longest voyage in the sample, however, and also the longest poem, Thomas Pearson chose the unpretentious form of iambic tetrameter couplets - he calls it 'this loose eight-foot careless verse' (l. 16). Pearson almost certainly did not intend his poem for publication, and it was only printed long after his death by John Nichols in tribute to his old friend. ${ }^{60}$ Written with the freedom of a man addressing an intimate friend, its style is unbuttoned, and it gives the impression of greater closeness to experience. 
The nine-month voyage it relates was from England to Calcutta, where Pearson was to join the East India Company, via Rio de Janeiro. Some, perhaps much, of the poem was written en route, and it conveys a lively sense of what shipboard travel was like. Partly this is a matter of day-to-day life - so that, for instance, a shark is caught while he is in the process of describing sharks (or so, writing to the moment, Pearson claims). Crucially, however, he reflects on the meaning of movement over distances that till the twentieth century were vast and over the timespans it required. This can be humorous, as when, after expatiating on the wisdom of Providence in not having made sharks any bigger, he justifies this theodicean detour with a topical quip: 'Yet, Shandy-like, tho’ I’m digressive, / My letter’s all the while progressive’ (ll. 172-4). But it can also take on a more sober note, as when, referring to the total isolation of a ship on such a journey from all kinds of external communication, he remarks: ‘An India voyage may be said, / To bury us before we're dead'. He goes on to call the ship a 'wooden grave’, and adds: 'In knowledge we don’t much exceed / Those who are really dead indeed’ (ll. 651-2, 653, 659-60). These reflections lead him to wonder what is going on in the Seven Years War, especially in the Belleisle expedition; who is poet laureate; and, also in humorous exaggeration, 'If Tristram Shandy yet be out' (1. 688). Pearson’s epistle has plenty of humour, as when he tells how his new hat got stolen in Rio or describes the crew, several of whom sailed with their wives. But it also strikes a solemn note in reflecting on those he has left behind - that his mother, whom he last saw 'mute with grief' (l. 701), may have died 'In blessing him who caused her death' (1. 708), or that 'Perhaps a Sister is no more' (l. 709). In these ways it is the most interesting and the most moving of the sample.

\section{Travel by various means}

The remaining epistles to be considered all represent more than one form of travel, so, as nearly all these forms have been discussed, each poem may be covered more briefly. 
Contrasting sharply with Pearson's is another poem about travelling to India, Eyles Irwin’s Occasional Epistles. Written During a Journey from London to Busrah [Basra]. Written in florid heroic couplets, and printed in a handsome quarto, each of the three epistles is prefaced by its own title page and a detailed 'Argument', a third of the 60 pages is taken up with endnotes, and some pages have footnotes too. As with Georgiana Cavendish's presentation piece, there is a direct relation between these high production values and paucity of reference to the actual processes of travel. Irwin must, for instance, have travelled by land as well as water, but he refers only to brief impediments to his journeys over the latter - the dropping of the wind on the Mediterranean, and what he assumed was Xenophon's 'Median wall' that obstructed his progress down the Tigris to Baghdad. ${ }^{61}$ Writing nearly 50 years earlier, and much closer to home, the former labourer Stephen Duck similarly declares, in his 'Description of a Journey to Marlborough': 'I will not sing each Trifle that occurr'd' (l. 23). Nevertheless, going one better than Gay’s 'Journey to Exeter', on which his poem is clearly modelled, Duck indicates that he not only combines equestrian transport with pedestrian, but goes from Southampton to Portsmouth by sea. Duck has none of Gay’s humour, and he is obliged to pay tribute to the patron he addresses in a way that Gay is not. His focus is less on the process of travelling than on sites of social, cultural-historical or, sometimes, personal interest. In this way he can turn within a few lines from Windsor, and 'Pope’s harmonious Song' (ll. 16-17), to ‘A Farmer, once the Author's Master, and still his Friend', as a footnote expresses it, and, in further acknowledgement of his previous life, to naming the village where he worked as a thresher (1. 52). Although Duck compliments the various people who helped him as he meets them or is reminded of them by his journey, it is in gratitude rather than servility; and he avoids packing in detail too closely by pacing his long epistle carefully, with occasional extended similes, and through fluent, correct versification.

While Irwin's motive for travelling was to rejoin the East India Company in which he 
served, and Duck’s was improvement and recreation, David Humphreys and John Thelwall had more unusual purposes. Humphreys, too, is the only writer among the sample who travelled in part by sleigh. His 'Letter to a Young Lady in Boston' describes his difficult journey from that city to Northampton, Massachusetts, on the way to join George Washington in the Revolutionary War. ${ }^{62}$ In what seems a well-judged attempt to amuse his addressee but not alarm her with the afflictions he encountered, Humphreys presents much circumstantial detail, including place-names with which he must have expected her to be familiar. The afflictions include 'downright cataracts' in a rainstorm, and 'paths of snow, too thin and soft', that cause the horses to flounder (197); a 'Slough Despond' in which the sleigh gets stuck (198); and three days of being 'weather bound' until a hard frost enables them to continue (199). Other accidents include one of his companions being bitten by a dog, dislocation of his 'better finger', and the sleigh overturning. Humphreys enlivens his iambic tetrameter couplets with comic double rhymes, such as ‘slump in’ / ‘jumping’ (198), ‘courage’ / 'porridge’ (199), and 'vehicle' / 'treacle' (200). But he strikes a serious note, too, as when he asks: 'But 'mid the roar of drums and guns, / Where meet again the muse's sons?', and closes with the promise: 'My conduct, till my final breath / Shall not disgrace my life or death' (201). Thelwall’s motive for travelling is less dramatic, though still unusual, because it is to get married. His journey, made in July, is also much easier, taking him from London to the Vale of Catmose in Rutland. Eager to join his bride, and finding that the Stamford coach does not run on Saturdays, Thelwall starts on foot. This is perhaps more significant than it seems, for, as mentioned above, pedestrian travel had democratic connotations in the Romantic period. Not only was the poem first published in a medley by Thelwall entitled The Peripatetic, but two years later, in his journal The Tribune, Thelwall called walking 'the true democratic way' of travel. ${ }^{63}$ As Nicholas Roe points out, 'Walking might therefore be construed in the 1790s as a deliberate expression of democratic opinions. ${ }^{64}$ Travelling in order to get married, Thelwall was 
Overton: page 28 of 46

nonetheless keen enough to arrive at his destination to beg a ride on the roof of a coach that comes along before he gets past Hatfield. Also, although, conventionally enough, he mentions the Earl of Warwick’s defeat at Barnet, he spends a verse paragraph apostrophising a group of gypsies met on the way as 'Poor harmless vagrants' whose way of life proclaims 'The darling boon of savage Liberty’ (114). This demonstrates the libertarian sympathies that were to get 'Citizen Thelwall' into trouble later. ${ }^{65}$ But his epistle is directed at the friend he calls 'Mercutio', whom he tries to dissuade from 'The town's lewd follies. and its sickly joys' (111). Arriving in Stamford after a night on the coach, therefore, he rejoices at the beautiful summer morning, and, having hired a horse for the journey’s last stage, closes by celebrating marriages based on mutual love such as that he is about to enter.

Two of the remaining three epistles describe journeys to and from Ireland respectively within two years of each other. While Moses Mendez, a wealthy stockjobber, travelled for pleasure, Samuel Derrick left Dublin to seek his fortune in London. ${ }^{66}$ The two suffer in different ways from the Irish Sea: Mendez from being stuck in a wherry for nearly four hours that makes little headway against the tide, Derrick more severely from being confined for three days by a contrary wind outside Dublin harbour. While Browne makes no bones about nausea, in the line already quoted, and Pearson prefers to avoid unpleasant details, merely remarking: 'So sea-sick was your humble servant, / It made him there the less observant' (ll. 64-5), Derrick conveys the same disagreeable information with a mock-heroic euphemism: 'Still as the vessel heav'd or tower'd, / Libations I to Neptune pour'd' (27). He has equal bad luck with the horse he hires. Having been assured: 'Sir, he’ll do any thing - but talk', Derrick finds him 'Starv'd, broken-winded, lame, and blind', so that, forced to go at the horse's own pace, both he and rider arrive at an inn 'founder'd quite' (30). Written to his countryman Francis Gentleman, who was already in London, the epistle no doubt exaggerates for humorous effect, but it also expresses genuine affection, ending as it does by looking forward to 'All the gay 
Overton: page 29 of 46

pleasures of the town', but with the proviso that 'pleasures sure they cannot be, / If not enjoy'd and shar'd by thee' (32). Mendez also writes to a close friend, the scrivener and fellow poet John Ellis, and he too closes with an expression of friendship: 'Let me know how in London you measure your time, / 'Twill be welcome in prose, but twice welcome in rhyme' (264). His request produced a response to his 'kind itinerary letter', as Ellis calls it, including a tribute to the liveliness of his account: 'Your journey you depict so strong, / Methinks I with you go along, ${ }^{67}$ Allowing for poetic licence, the compliment is just. Though he begins with a humorous allusion to 'the lyre of Apollo, the locks of the Muses', Mendez gives no sign of wishing to impress either his addressee or any other reader. His anapestic tetrameter couplets are not only pleasantly unostentatious but allow ample room for description and commentary. This includes historical allusions that are unconventionally droll and disrespectful, as when he refers to Dunstable 'Where the Eighth of our Harries deserted his mate, / And procur'd a full sentence against his old Kate', outspoken exposure of the 'dirty worm-eaten abodes' and 'foul manners' that he finds at Coventry (258), the uselessness of English in much of North Wales, naming and complimenting his host at Chester (260), and the need from Flint to Conwy of a guide (261). He gives details not only of his route and the weather, which includes snow and rain, but his manner of travelling, ranging from 'a coach and six horses' (258) to a traverse on foot of cliffs near Penrhyn Rhos (261-2), 'a leaky old boat’ across the river Conwy (262), and a chaise to Holyhead (263). Mendez can also convey a sense of his journey as he experienced it, as when, describing the cliff-crossing, he exclaims: 'How narrow the path, observe where you tread, / Nor stumble the feet, nor grow dizzy the head' (262).

It is, then, the humble familiar epistle that often conveys the most vivid experience of travel. Like Mendez 50 years earlier, Eliza Day also used anapestic metre for her account of a trip to the glaciers of Savoy, though she cast them in trimeter quatrains rather than tetrameter couplets. ${ }^{68}$ The form is especially well suited to describing the jars and jolts caused by rocky 
surfaces, as her description of transport by Alpine charabanc indicates. Day explains in a footnote that a charabanc is 'a wooden machine to convey passengers of the mountains, in shape like the long carriages for musical instruments', adding that, 'having no springs, the motion is inexpressibly rough' (164-5). This her verse humorously suggests through its strong rhythms and occasional double rhymes, for example:

Such twistings and jerkings there were, Predetermin'd to heartily bump us;

Zig-zag, like a dog in a fair, To all the four points of the compass. (164)

Day nicely combines the response expected from the impressed tourist with a down-to-earth concern for her safety:

Yet though 'twas enchantingly fine, Très superbe, magnifique, the rude murmur, Still the part I thought nearest divine, Was when my feet touch'd terra firma. (167)

She conveys an equally rueful response to a thunderstorm that reduces the party to 'a parcel of rats' (167), riding on one of the mules that 'go as they chose' (169), trudging 'near four mile' over terrain 'Fit for no earthly foot, - save a goat', and, finally, being bitten to pieces by 'Bugs and fleas’ at Martigny (170). It is scarcely surprising that she ends with an early case of tourism fatigue, ‘For a season, quite sicken’d with sights’ (171). 
Overton: page 31 of 46

Ranges, motives and implications

The 25 poems discussed in this essay reflect the improvements in transport and communication mentioned at the start. They represent not only various methods of travel (on foot, on horseback, and in a wide range of vehicles and vessels), but a striking range of starting-points and destinations, and also distances travelled. The longest journey, by sea, took nine months; the shortest, on horseback, a single day (recounted in the poems by Thomas Pearson and John Whaley respectively). Perhaps unexpectedly, the social range of the writers is also broad, extending from three labouring-class poets (Stephen Duck, William Vernon, Alexander Wilson) to a Duchess (Georgiana Cavendish). In between are members of the Anglican clergy (Sneyd Davies, Samuel Dent, Francis Fawkes, Richard Polwhele, John Whaley), the professional bourgeoisie (John Byrom, William Cockin, Eyles Irwin, Thomas Pearson, John Thelwall), the commercial bourgeoisie (Moses Browne, William Chatterton, Eliza Day, Moses Mendez, Priscilla Pickering), an aide-de-camp in the American Revolutionary Army (David Humphreys) and the gentry (Thomas Gilbert and, probably, two of the anonymous writers). More surprising is the fact that only one of the group, John Gay, could be called a professional writer, though even he largely depended on patronage, and though Samuel Derrick was to succeed as an author once established in London.

The sample bears out three generalisations by James Duncan and Derek Gregory about the development of modern travel. First, it was deeply connected with secularisation; second, it quickly came to be seen 'as an end in itself, as a form of pure pleasure'; and, third, it was by no means 'an exclusively aristocratic preserve'. ${ }^{69}$ The motives for travelling revealed by each poem are certainly secular. Eleven describe journeys for career or professional reasons (if those terms are not too lofty for one published anonymously about becoming a pirate), and a further ten for pleasure; but in three the reason for the journey is social (in one case, Thelwall's, nuptial), and in one (that by Humphreys) it is military. ${ }^{70}$ Although the wide social range of the 
Overton: page 32 of 46

writers indicates that travelling was by no means limited to those high in the social scale, the sample includes only three poems by female writers - Cavendish, Day, and Pickering. There are probably two main reasons for this slender representation. One is that, as Susan Bassnett remarks, 'early travel accounts tended for the most part to be written by men, who moved more freely in the public sphere'. ${ }^{71}$ The other, as Elizabeth A. Bohls points out, is that women writers 'were less likely to venture into public authorship at the time'. ${ }^{72}$ Bohls also declares that 'Women were less likely to venture into public than men, with the result that some of the best travel literature of the period (represented [in her anthology] by Dorothy Wordsworth, Janet Schaw, and Maria Nugent, as well as [Celia] Fiennes) remained unpublished until a later generation'. ${ }^{73}$ But because poetry, as well as polite fiction, became established as a legitimate form of publication for women during the century, these three women at least got their accounts of journeys into print - in Pickering's case all the more impressively because she travelled alone and was completely blind. The fact that the journeys the three wrote about were all for pleasure therefore also reflects both the growth in tourism mentioned by Duncan and Gregory and women’s increased access to publication.

After considering examples of topographical poems by Sir John Denham, John Dyer and William Crowe, Robin Jarvis remarks that they show 'the gradual transformation of the walker from an organising trope encumbered with political, moral and aesthetic agendas of an adventitious or externally validated nature, to a more material figure-in-the-landscape possessed of an unfolding selfhood whose health and identity are bound up with the excursionary experience itself' ${ }^{74}$ The travel-epistles I have discussed provide further evidence of this point, and even suggest that the transformation to which Jarvis refers began a little earlier. Although not every one of the poems in the sample makes much reference to the physical details of travel, there is none that does not extend awareness of its diversity and importance. These poems demonstrate, most of all, the emerging ideology of mobility early in 
Overton: page 33 of 46

the modern period. The fact that they are all epistles enables them, at their most direct, to represent travel with particular vividness and interest. During a century in which the opportunities to travel and communicate even over long distances increased rapidly, and in which it became possible for people of all social classes to publish their writing, the verse epistle proved an especially apt form in which to represent journeying. 
Overton: page 34 of 46

\section{References}

A shorter version of this essay was presented at the 3rd International Paul-Gabriel Boucé

Colloquium on Eighteenth-Century Studies at the Université de la Sorbonne Nouvelle Paris III, on 15 December 2006. For full publication details of the poems, see the list at the end.

1. Nigel Thrift, 'Transport and Communication 1730-1914', in An Historical Geography of England and Wales, ed. by R. A. Dodgshon and R. A. Butlin, 2nd edn (London and New York: Academic Press, 1990), 453-86 (453).

2. Karina Williamson, 'Voice, Gender, and the Augustan Verse Epistle’, in Presenting Gender: Changing Sex in Early-Modern Culture, ed. by Chris Mounsey (Lewisburg, PA: Bucknell University Press; London: Associated University Presses, 2001), 76-93 (76).

3. See Bill Overton, 'The Verse Epistle', in A Companion to Eighteenth-Century Poetry, ed. by Christine Gerrard (Malden, MA and Oxford: Blackwell Publishing, 2006), 417-28; and The Eighteenth-Century British Verse Epistle (Houndmills, Basingstoke, and New York: Palgrave Macmillan, 2007).

4. William C. Dowling, The Epistolary Moment: The Poetics of the Eighteenth-Century Verse Epistle (Princeton: Princeton University Press, 1991), 21.

5. Clare Brant, Eighteenth-Century Letters and British Culture (Houndmills, Basingstoke, and New York: Palgrave Macmillan, 2006), 2.

6. Thrift, 'Transport and Communication 1730-1914', 454.

7. $\quad$ Critical Review, quoted in Katherine Turner, British Travel Writers in Europe 17501800: Authorship, Gender, and National Identity (Aldershot: Ashgate, 2001), 2.

8. Tim Cresswell, On the Move: Mobility in the Modern Western World (New York and London: Routledge, 2006), 1-24 (14).

9. Cresswell, On the Move, 15, quoting Nick Blomley, Law, Space and the Geographies of 
Overton: page 35 of 46

Power (New York: Guilford, 1994), 209. The passage cited is from Blackstone, Commentaries, 4 vols (Oxford: at the Clarendon Press, 1765-9), I, 130, with the word 'loco-motion' incorrectly rendered as 'loco-movement'.

10. Interference with private mail was, however, commonplace in the eighteenth century. Kenneth Ellis states that it was given 'an unassailable legal basis' by the Post Office Act of 1711, and, as a result, 'By custom, mail was opened freely on suspicion, or in search of designated letters, or on informal orders from Under Secretaries of State' (The Post Office in the Eighteenth Century: A Study in Administrative History [London: Oxford University Press, 1958], 63, 64-5). Howard Robinson similarly writes: 'Letters were opened officially to detect customs violations, to trace robberies, to find the actual financial conditions of bankrupts, as well as to inquire after treasonable actions’ (Britain's Post Office: A History of Development from the Beginnings to the Present Day [London: Oxford University Press, 1953], 91).

11. Jarvis, Romantic Writing and Pedestrian Travel (Houndmills, Basingstoke: Macmillan; New York: St Martin’s Press, 1997), 6, citing Wallace, Walking, Literature and English Culture: The Origins and Uses of Peripatetic in the Nineteenth Century (Oxford: Clarendon Press, 1993).

12. Brant, Eighteenth-Century Letters and British Culture, 229, 230.

13. Janet Gurkin Altman makes this 'simple distinction', as she calls it, in Epistolarity: Approaches to a Form (Columbus: Ohio State University Press, 1982), 112, n. 1, relating it to Gérard Genette’s terms ‘intradiegetic’ and 'extradiegetic’. Dowling uses similar terminology but, at least for Augustan poetry, prefers the terms 'lector' and 'epistolary audience’. See Epistolary Moment, 3-13.

14. Altman, Epistolarity, 112, n. 2.

15. Epistolarity, 111; see especially Chapter 3, 'The Weight of the Reader'. 
Overton: page 36 of 46

16. Davies, 'A Voyage to Tinterne Abbey in Monmouthshire, from Whitminster in Glocestershire’; Duck, ‘A Description of a Journey to Marlborough, Bath, Portsmouth, \&c. To the Right Honourable the Lord Viscount Palmerston’; Irwin, Occasional Epistles. Written During a Journey from London to Busrah; Whaley, ‘A Journey to Houghton’.

17. Byrom, A Full and True Account of an Horrid and Barbarous Robbery, repr. in Poems of John Byrom, I, 62-73 (70).

18. Mendez, 'The Author's Account of his Journey to Ireland. To Mr. John Ellis', Collection of the Most Esteemed Pieces of Poetry, 257-64; Day, 'A Tour to the Glaciers of Savoy. An Epistle to John Waller, Esq.', Poems and Fugitive Pieces, 162-71.

19. 'Cynthio to Leonora. An Epistle from the Cape of Good Hope'.

20. Epistle to D[aniel] B[raithwaite]. By T[homas] P[earson].

21. Thelwall, in Peripatetic, II, 77-83; Poems by Mrs. Pickering, 35-45.

22. Vernon, ‘A Journey to Wales. Humbly Inscrib’d to the Reverend Mr. Williams, of Weston’, Poems on Several Occasions, 6-12.

23. The subscription list locates Weston in Shropshire (p. xiv); it may have been Westonunder-Lizard, near Weston Park.

24. Wilson, 'Poetical Letter to William Duncan, his Nephew, Seneca County, New York State', The Poems and Literary Prose of Alexander Wilson, II, 187-90. The journey probably took place in April 1799, Duncan having made an exploratory visit the previous autumn. See 'Letter XIII' and 'Letter XIV', Poems and Literary Prose, I, 69-70; and Frank L. Burns, ‘Alexander Wilson. VIII. His Early Life and Writings’, Wilson Bulletin, 22:2 (March-April 1910), 79-96 (85).

25. 'Wilhalvossing' may refer to Wyalusing, 'Lelu' possibly to the Lehigh river.

26. David F. Foxon, English Verse 1701-1750, 2 vols (Cambridge: Cambridge University Press, 1975), I, 299 (G88); dated erroneously in Poetry and Prose. 
Overton: page 37 of 46

27. David Nokes, John Gay: A Profession of Friendship (Oxford: Oxford University Press, 1995), 218.

28. As Dearing and Beckwith note, the reference anticipates 'Robin of Bagshot' in Gay's The Beggar's Opera (Poetry and Prose, II, 582). For details of eighteenth-century highway robbery, see Gillian Spraggs, Outlaws and Highwaymen: The Cult of the Robber in England from the Middle Ages to the Nineteenth Century (London: Pimlico, 2001), especially chapters 13-19. Dr Spraggs is also the author of an unpublished paper, 'Gentlemen of the Road: Highwaymen on Bagshot Heath', which she kindly made available to me and which points out that Bagshot is also mentioned in connection with Macheath early in The Beggar's Opera (Act 1, Scene 4, lines 42-5).

29. Poetry and Prose, II, 581.

30. The letter is printed in Maynard Mack, Collected in Himself: Essays Critical, Biographical, and Bibliographical on Pope and Some of His Contemporaries (Newark, NJ: University of Delaware Press; London: Associated University Presses, 1982), 470-1.

31. E.g., by Mack and by Nokes (221-3).

32. Whaley, Collection of Original Poems and Translations, 29-51.

33. The line 'But found not Hay for Horse, nor Meat for Man' (31) reverses Gay's 'Here is for Horses Hay, and Meat for Men’ (125-6).

34. Quoted by Karen O’Brien in her ODNB article on Whaley.

35. Walpole died on 18 March 1745; Whaley, according to Horace Walpole, in December of the same year $(O D N B)$. Foxon notes an advertisement for Whaley's Collection in the Gentleman's Magazine for August 1745 (English Verse 1701-1750, I, 888), but it is not clear exactly when the poem was written. If the journey was made in the previous summer, and the poem composed soon after, the lines referring to Walpole's death must have been revised or added later. 
Overton: page 38 of 46

36. Poems, By the Late Mr. Stephen Chatterton, 72-5.

37. Gilbert, Poems on Several Occasions, 211-16.

38. See the $O D N B$ article on Hall-Stevenson by David Oakleaf.

39. Rosamond Bayne-Powell, Travellers in Eighteenth-Century England (London: John Murray, 1951), 10-11. For an overview of road transport in the period, see H. J. Dyos and D. H. Aldcroft, British Transport: An Economic Survey from the Seventeenth Century to the Twentieth [1969] (Harmondsworth: Penguin Books, 1974), 34-7, 66-84; and Philip S. Bagwell, The Transport Revolution [1974] (London: Routledge, 1988), Chapter 2.

40. 'The Journey; A Familiar Epistle from the Country to Mr. G. R—y, Painter in London', Occasional Attempts in Verse. By W. C., 78-93 (86). Cockin’s destination was Burton in Kendal $(O D N B)$.

41. The 1770 edition of Richard Baldwin's 'Account of all the Stage-Coaches and Carriers in England and Wales' indicates that the Kendall coach left on Monday mornings at 3, and that the fare was $£ 3$. $7 \mathrm{~s}$, or between $3 \frac{1}{4} 4 \mathrm{~d}$ and $3 \frac{1}{2} \mathrm{~d}$ per mile for what Cockin says was a total of ‘twelve score miles’ (86). See Baldwin’s New Complete Guide, 12th edn (London: for Richard Baldwin and others), 217.

42. V. A. C. Gatrell notes that 'The 1752 Murder Act had regularized ancient practice by permitting judges to order murderers' gibbeting as part of the sentence in court. On Hounslow Heath up to a hundred gibbets were said to have stood in the 1770s.' See The Hanging Tree: Execution and the English People, 1770- 1868 (Oxford: Oxford University Press: 1996), 267-9 (267).

43. Poems of John Byrom, I, 62-73.

44. A note in the 1773 edition of Byrom's Works, reprinted in the Chetham Society edition, indicates that the characters had been cut out by Byrom's sister. The highwayman's 
Overton: page 39 of 46

superstitious response suggests ignorance as well as nervousness.

45. Quoted in Poems, I, 62. Subsequent letters confirm safe arrival of boots and return to London; see The Private Journal and Literary Remains of John Byrom, 4 vols, ed. by Richard Parkinson (Manchester: Chetham Society, 1854-57), I, 288-93.

46. For biographical information, see Eighteenth-Century Women Poets: An Oxford Anthology, ed. by Roger Lonsdale (Oxford: Oxford University Press, 1989), 272-3. Pickering had published an earlier collection under her maiden name, Poems on Several Occasions (Birmingham: for the author by T. Warren, 1770). The journey probably took place after 1788 because she refers to a house in Saughall (35) that she is most likely to have acquired after her marriage in that year.

47. Pickering's first collection attracted a large number of subscribers. Though there is no subscription list in her second, its co-contributor and editor, Joseph Weston, indicates in his Preface that many of the poems had been damaged through handling by prospective subscribers ([iii]-iv).

48. Cockin's title-page indicates that his collection was 'printed only for the writer's particular acquaintance’.

49. Cavendish, Passage of the Mountain of Saint Gothard, repr. in Eighteenth-Century Women Poets, 511-14; Polwhele, 'Epistle to Dr. Downman of Exeter. Written at Manaccan, 1794’, Poems, III, 247-55; Fawkes, ‘A Journey to Doncaster, or a Curious Journal of Five Days, Wrote, with a Pencil in a Chaise', The Poetical Calendar, IX, 10511.

50. Foreman, Georgiana, Duchess of Devonshire (London: HarperCollins, 1998), 324, 323.

51. Polwhele, The Unsex'd Females (London: for Cadell and Davies, 1798); see ODNB.

52. Dyos and Aldcroft, British Transport: An Economic Survey from the Seventeenth Century to the Twentieth, 75. 
Overton: page 40 of 46

53. Davies, ‘A Voyage to Tinterne Abbey’, 188; lines 59-82 repr. in The New Oxford Book of Eighteenth-Century Verse, ed. by Roger Lonsdale (Oxford: Oxford University Press, 1984), 398-9.

54. Browne, 'Epistle I. The Voyage', 205; Duick, 'Scarborough. A Poem’, in The Scarborough Miscellany for the Year 1733 (London: for J. Wilford, 1734), 1-18.

55. A Journey from London to Scarborough (London: for Cæsar Ward and Richard Chandler, 1734), 1, 2.

56. N — ' 'Voyage to Guernsey’, Gentleman’s Magazine, XXVII (January 1757), 35.

57. For details on privateers operating out of Guernsey, including one called The Adventure in 1746-7, see, e.g., London Magazine, 15 (1746), 362, and The British Magazine: Or, the London and Edinburgh Intelligencer. For the Year 1747 (Edinburgh: by T. Lumisden and Company, 1748?), 142.

58. $N \_$- 'An Epistle written on board the Adv-t-re Privateer', Gentleman's Magazine, XXVII (April 1757), 180.

59. Dent, An Epistle to a Friend in England. Written at Sea, in December. The poem was published anonymously, and is attributed to Dent in the Bodleian Library copy. The Yorkshire Magazine later records: 'The Rev. Samuel Dent, of Bridgetown in Barbadoes, (a native of Whitehaven) has discovered the veritable nankeen dye, which has so long been the object of inquiry’ (York: for T. Wilson, R. Spence, and Crask \& Lund, 1786), I, 222.

60. According to Simon May of the British Library, for whose help I am grateful, the poem was probably printed between 1802 and 1805 . This may have been to coincide with a memoir of Pearson, who had died in 1781, that appeared in the European Magazine in April 1804 (XLV, 243). Braithwaite had been one of the proprietors of the Magazine, edited by Isaac Reed, and it is to Reed, who had also been a friend of Pearson, that 
Overton: page 41 of 46

Arthur Sherbo attributes the memoir in 'Isaac Reed and the European Magazine', Studies in Bibliography, 37 (1984), 210-27 (219-20).

61. Irwin, 'Epistle II. From Laodicea’, 113-15; 'Epistle III. From Coorna, on the Conflux of the Tigris and Euphrates’, 157-162 (160).

62. The Miscellaneous Works of David Humphreys, 196-201.

63. Quoted by Michael Scrivener in Seditious Allegories: John Thelwall and Jacobin Writing (University Park: The Pennsylvania State University Press, 2001), 209. When the poem was reprinted in Poems (1805?), it was revised, including the omission of 40 lines, but a footnote indicated that it was 'From the Peripatetic' (110).

64. Nicholas Roe, The Politics of Nature: Wordsworth and Some Contemporaries (Houndmills and London: Macmillan, 1992), 128.

65. On Thelwall's career as a political agitator, see Scrivener, Seditious Allegories, and Damian Walford Davies, Presences That Disturb: Models of Romantic Identity in the Literature and Culture of the 1790s (Cardiff: University of Wales Press, 2002), especially 193-240.

66. Moses Mendez, 'The Author’s Account of his Journey to Ireland. To Mr. John Ellis', A Collection of the Most Esteemed Pieces of Poetry, That Have Appeared for Several Years, 257-64; Gilbert, 'A Voyage from Dublin to Chester. In an Epistle to Lieutenant Francis Gentleman, Anno 1746’, A Collection of Original Poems, 26-32.

67. Ellis, 'The Answer', A Collection of the Most Esteemed Pieces of Poetry, 264-6 (264). This is absent from the second edition (1770).

68. Day, 'A Tour to the Glaciers of Savoy. An Epistle to John Waller, Esq.'; lines 29-136 repr. in Eighteenth-Century Women Poets: An Oxford Anthology, 496-9.

69. James Duncan and Derek Gregory, 'Introduction', in Writes of Passage: Reading Travel Writing, ed. by James Duncan and Derek Gregory (London and New York: Routledge, 
Overton: page 42 of 46

1999), 1-13 (6).

70. Epistles indicating career motives are: Anonymous, 'Cynthio to Leonora’; Anonymous, 'Voyage to Guernsey’; Byrom, Horrid and Barbarous Robbery; Chatterton, ‘Journey’; Cockin, ‘Journey’; Dent, ‘Epistle to a Friend'; Derrick, ‘Voyage from Dublin to Chester'; Irwin, Occasional Epistles; Pearson, Epistle to D. B.; Polwhele, 'Epistle to Dr. Downman’; Wilson, ‘Poetical Letter to William Duncan’; pleasure motives: Day, ‘Tour to the Glaciers of Savoy’; Davies, 'Voyage to Tinterne Abbey’; Browne, 'Voyage’; Cavendish, Passage of the Mountain of St. Gothard; Duck, 'Description of a Journey to Marlborough’; Gay, ‘Epistle to Burlington’; Gilbert, ‘Familiar Epistle to Doctor Reeve’; Mendez, 'Journey to Ireland'; Vernon, 'Journey to Wales’; Whaley, ‘Journey to Houghton’; social motives: Fawkes, ‘Journey to Doncaster’; Pickering, ‘Journal from Litchfield to Chester’; Thelwall, ‘Epistle to Mercutio’; military motive: Humphreys, 'Letter to a Young Lady in Boston'.

71. Susan Bassnett, 'Travel Writing and Gender', in The Cambridge Companion to Travel Writing, ed. by Peter Hulme and Tim Youngs (Cambridge: Cambridge University Press, 2002), 225-41 (225).

72. Elizabeth A. Bohls, 'Introduction', Travel Writing 1700-1830: An Anthology, ed. by Elizabeth A. Bohls and Ian Duncan (Oxford and New York: Oxford University Press, 2005), xxvii.

73. Bohls, 'Note on the Text', Travel Writing 1700-1830, xxviii.

74. Jarvis, Romantic Writing and Pedestrian Travel, 77. 
Overton: page 43 of 46

List of Poems Discussed

Anonymous, ‘Cynthio to Leonora. An Epistle from the Cape of Good Hope’, Gentleman’s Magazine, VIII (June-July 1738), 319, 370-1

— ('N__'), 'A Voyage to Guernsey, in an Epistle to a Lady in London', Gentleman’s Magazine, XXVII (January 1757), 35, repr. in English Originals in Prose and Verse Collected by I. L. Schulze, 2nd edn (Hall[e]: n. p., 1766), 262-4

Browne, Moses, 'A View of Scarborough, in Four Epistles, to a Friend in Town’, 'Epistle I. The Voyage', Poems on Various Subjects (London: by and for Edward Cave, 1739), 205-11

Byrom, John, A Full and True Account of an Horrid and Barbarous Robbery, Committed on Epping-Forest, Upon the Body of the Cambridge Coach (London: by J. Roberts, 1728), repr. in The Poems of John Byrom, ed. by Adophus William Ward, 3 vols (Manchester: Charles E. Simms for the Chetham Society), I, 62-73

[Cavendish], Georgiana, Duchess of Devonshire, The Passage of the Mountain of Saint Gothard ([London?]; n. p., [1798?]); repr. in Eighteenth-Century Women Poets: An Oxford Anthology, ed. by Roger Lonsdale (Oxford: Oxford University Press, 1989), 51114

Chatterton, Stephen, 'The Journey. An Epistle to Mr. Pardoe’, Poems, by the Late Mr. Stephen Chatterton (London: for the author's widow, 1795), 72-5

C[ockin], W[illiam], 'The Journey; A Familiar Epistle from the Country to Mr. G[eorge] R[omne]y, Painter in London’, Occasional Attempts in Verse. By W. C. (Kendall: for the writer's particular acquaintance by W. Pennington, 1776), 78-93

D[avies], [Sneyd], 'A Voyage to Tinterne Abbey in Monmouthshire, from Whitminster in Glocestershire', in John Whaley, A Collection of Original Poems and Translations (London: for the author, 1745), 187-91, lines 59-82 repr. in The New Oxford Book of 
Overton: page 44 of 46

Eighteenth-Century Verse, ed. by Roger Lonsdale (Oxford: Oxford University Press, 1984), 398-9

[Day], Eliza, 'A Tour to the Glaciers of Savoy. An Epistle to John Waller, Esq.', Poems and Fugitive Pieces, by Eliza (London: by W. Bulmer and Co., 1796), 162-71, lines 29-136 repr. in Eighteenth-Century Women Poets, ed. by Roger Lonsdale (Oxford: Oxford University Press, 1989), 496-9

Dent, Samuel, An Epistle to a Friend in England. Written at Sea, in December, 1772. With an Hymn Annexed ([London?]: n. p., [1773?]), repr. without the hymn in The London Magazine. Or, Gentleman’s Monthly Intelligencer, XLIII (February 1773), 93-4

Derrick, Samuel, ‘A Voyage from Dublin to Chester. In an Epistle to Lieutenant Francis Gentleman, Anno 1746', A Collection of Original Poems (London: for the author, 1755), 26-32

Duck, Stephen, 'A Description of a Journey to Marlborough, Bath, Portsmouth, \&c. To the Right Honourable the Lord Viscount Palmerston', Poems on Several Occasions (London: for the author, 1736), 205-36, repr. in Eighteenth-Century English Labouring-Class Poets, 3 vols, gen. ed. John Goodridge (London: Pickering \& Chatto, 2003), I (17001740), ed. by William Christmas, 156-69

Gay, John, 'An Epistle to the Right Honourable the Earl of Burlington. A Journey to Exeter', John Gay: Poetry and Prose, 2 vols, ed. by Vinton A. Dearing with the assistance of Charles E. Beckwith (Oxford: Clarendon Press, 1974), I, 203-7

Gilbert, Thomas, ‘A Familiar Epistle to Doctor Reeve, in London', Poems on Several Occasions (London: for Charles Bathurst, 1747), 211-16

Fawkes, Francis, 'A Journey to Doncaster, or a Curious Journal of Five Days, Wrote, with a Pencil in a Chaise', The Poetical Calendar, 12 vols, 2nd edn (London: by Dryden Leach for J. Coote, 1763-4), IX, 105-11 
Overton: page 45 of 46

Humphreys, David, 'A Letter to a Young Lady in Boston', The Miscellaneous Works of David Humphreys, rev. edn (New York: by T. and J. Swords, 1804), 196-201

Irwin, Eyles, Occasional Epistles. Written During a Journey from London to Busrah, in the Gulf of Persia, in the Years 1780 and 1781 (London: for J. Dodsley, 1783)

Mendez, Moses, ‘The Author’s Account of his Journey to Ireland. To Mr. John Ellis’, A Collection of the Most Esteemed Pieces of Poetry, That Have Appeared for Several Years (London: for Richardson and Urquhart, 1767), 257-64

P[earson], T[homas], Epistle to D. B. By T. P. ([London]: by J. Nichols and Son, [1804?]), BL shelfmark 1465.f.58

Pickering, Priscilla (née Pointon), ‘A Journal from Litchfield to Chester’, Poems by Mrs. Pickering (Birmingham: by E. Piercy, [1794]), 35-45

Polwhele, Richard, 'Epistle to Dr. Downman of Exeter. Written at Manaccan, 1794', Poems, 3 vols (London: for T. Cadell, 1806), III, 247-55

Thelwall, John, 'Epistle to Mercutio', in The Peripatetic; Or, Sketches of the Heart, of Nature and Society; In a Series of Politico-Sentimental Journals, in Verse and Prose, of the Eccentric Excursions of Sylvanus Theophrastus; Supposed to be Written by Himself, 3 vols ([Southwark]: for the author, 1793), II, 77-83; John Thelwall, The Peripatetic, ed. with an Introduction by Judith Thompson (Detroit: Wayne State University Press, 1981), 211-16; rev. version in Poems, Chiefly Written in Retirement, 2nd edn ([Hereford]: n. p., [1805?]), 110-16

Vernon, William, ‘A Journey to Wales. Humbly Inscrib’d to the Reverend Mr. Williams, of Weston', Poems on Several Occasions (London: for the author, 1758), 6-12; first printed in Gentleman’s Magazine, XXVII (May 1757), 226-7; repr. in Eighteenth-Century English Labouring-Class Poets, 3 vols, gen. ed. John Goodridge (London: Pickering \& Chatto, 2003), II (1740-1780), ed. by Bridget Keenan, 100-3 
Overton: page 46 of 46

Whaley, John, 'A Journey to Houghton, the Seat of the Right Hon. Robert Walpole, Earl of Orford, in the County of Norfolk', A Collection of Original Poems and Translations (London: for the author, 1745), 29-51

Wilson, Alexander, 'Poetical Letter to William Duncan, his Nephew, Seneca County, New York State', The Poems and Literary Prose of Alexander Wilson, ed. by Alexander B. Grosart, 2 vols (Paisley: Alex. Gardner, 1876), II, 187-90 